\title{
Species richness and longitudinal distribution of crustaceans in the Logawa River, Banyumas, Indonesia
}

\author{
MOH. HUSEIN SASTRANEGARA ${ }^{\star}$, KUSBIYANTO" \\ Faculty of Biology, Universitas Jenderal Soedirman. Jl. dr. Soeparno 63, Purwokerto Utara, Banyumas 53122, Central Java, Indonesia.

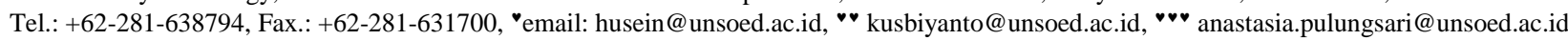

Manuscript received: 28 November 2019. Revision accepted: 22 October 2020.

\begin{abstract}
Sastranegara MH, Kusbiyanto, Pulungsari AE. 2020. Species richness and longitudinal distribution of crustaceans in the Logawa River, Banyumas, Indonesia. Biodiversitas 21: 5322-5330. The Logawa River originates in a forest on Slamet Mountain and empties into the Serayu River. In this river, crustaceans play an important role as river macrobenthos. This research aimed to evaluate the species richness and longitudinal distribution of crustaceans. The research method was a stratified random sampling technique at eight stations with five replicates. Crustacean samples were collected using a Surber net, and water samples were taken with a water sampler. The results showed that there were six species of Decapoda in the river. Of these six species, three were shrimps and three were crabs. In longitudinal distribution, the shrimp Macrobrachium idae could be categorized as a cosmopolitan species that inhabited all stations, although there were several river branches before Stations IV (Cangkring Stream), V (Mengaji Stream), and VI (Banjaran Stream), bedrock substrate at Station I, high ammonia at all stations and high chemical oxygen demand (COD) between Stations IV and VIII. The crab Varuna litterata was found only at Station VI. In general, the species richness decreased after Station IV due to COD from the riverside. This was caused by human activities such as stone and sand excavation and overfishing in the habitat. The upstream habitat with its bedrock substrate was not suitable for decapods, except for cosmopolitan species.
\end{abstract}

Keywords: Decapoda, river branching, riverside, substrate, water quality

\section{INTRODUCTION}

Lotic waters can be fresh or brackish. Freshwater flows from upstream to downstream and through areas of differing topography, and streams and tributaries can be merged along with the flow (Duya 2008). Such waterways have a function in storing and draining water from rainfall and other water sources. Water storage and drainage areas are arranged according to the natural conditions around them (Lazo et al. 2019).

Natural and anthropogenic disturbances can affect the species richness of organisms such as crustaceans that inhabit rivers. Environmentally detrimental methods of catching river species, such as the use of poisons and other chemicals, can threaten the presence of crustaceans and affect catches. Therefore, the understanding of biological and environmental parameters needs to be optimized to maintain the availability of wild products (Deekae and Abowei 2010). By collecting species richness data, researchers can gain insight into longitudinal distributions to map species distributions (Altermatt et al. 2014).

The Logawa River traverses various topographies, originating in a forest on the south slope of Slamet Mountain in Baturraden Sub-district, Banyumas District, Central Java Province, Indonesia, and emptying into the Serayu River. The Logawa River is about $25 \mathrm{~km}$ long from upstream to downstream. In some locations, human activities such as sand and stone excavation are destroying crustacean habitats. From the upstream to the downstream areas of the river, riversides are bounded by forest and garden areas, followed by rain-filled rice fields, irrigated rice fields, inorganic waste pollution in the form of moor disposal, and organic waste pollution from settlements. Along the river, there is fishing activity using both fishing equipment and chemicals, which are disposed of in the river waters and cause decreases in some water quality parameters.

Studies have reported on crustacean species richness in various regions (Howard et al. 2015; Ng 2004; Sastranegara et al. 2020). Research on macrobenthic organisms, including insects, gastropods, and annelids, has also been carried out in the Logawa River (Wibowo et al. 2017). The altitudinal, latitudinal, and longitudinal distribution of freshwater amphipod species has been reported from Switzerland (Crustacea: Amphipoda) (Altermatt et al. 2014). However, the species richness and longitudinal distribution of freshwater decapod shrimp and crab species (Crustacea: Decapoda) have never been studied in this river. Therefore, research into the species richness and longitudinal distribution of crustaceans is important. Information from this research provides a necessary scientific foundation for the formulation of river management policies.

The purpose of this study was to evaluate the species richness and longitudinal distribution of crustaceans in the Logawa River in Banyumas, Indonesia. The findings of this study offer a scientific foundation for policies concerning the management of the Logawa River and the conservation of crustaceans. 


\section{MATERIALS AND METHODS}

\section{Study area}

This research was conducted at eight stations (Stations I-VIII) along the Logawa River in Banyumas District, Central Java Province, Indonesia (Figure 1). Fieldwork was conducted for 3 months with five sampling replicates every 2 weeks, i.e., $16^{\text {th }}$ June $2019,30^{\text {th }}$ June $2019,14^{\text {th }}$ July 2019, 28 ${ }^{\text {th }}$ July 2019, and $12^{\text {th }}$ August 2019. Crustacean identification was carried out at the Aquatic Biology Laboratory, Faculty of Biology, Universitas Jenderal Soedirman, Purwokerto, Indonesia, and water quality analyses were conducted at the Environmental Laboratory of the faculty.
The characteristics of each station varied based on their coordinates, altitude, riverside, substrate types, human activities, width, depth, and location (Table 1). There were some branches in the river system before Stations IV, V, and VI (Figure 1).

\section{Crustacean and water quality sampling}

Crustacean and water quality samples were taken from the same study area. Shrimp and crab samples were preserved in alcohol. This study used a survey method employing a stratified random sampling technique with locations determined from upstream to downstream. Some stations were located after branches in the river system. From these streams and tributaries, the origin of species richness could be predicted.
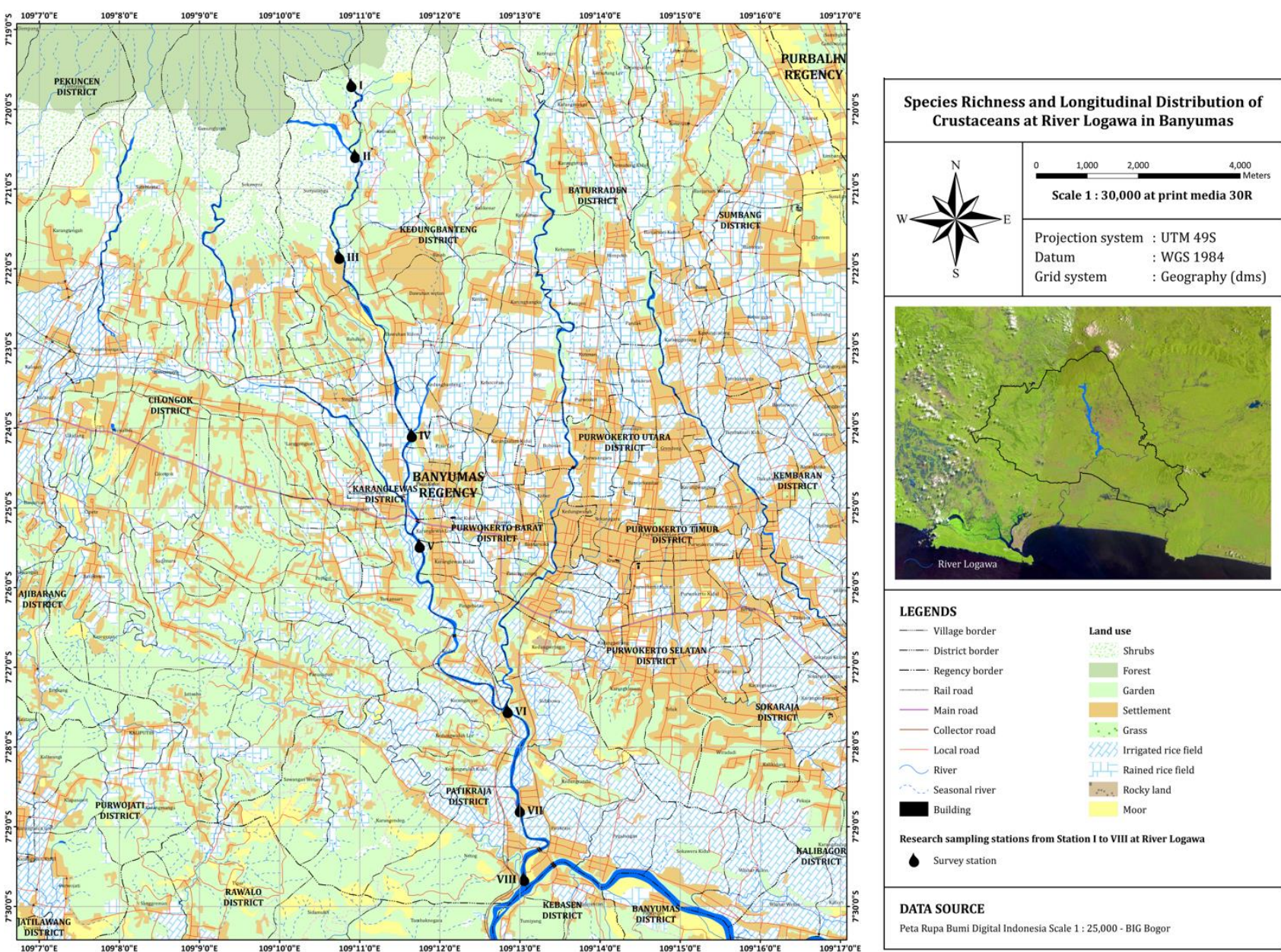

Figure 1. Location of the Logawa River, Banyumas District, Indonesia indicating the crustacean sampling sites: Station I $\left(07^{\circ} 19^{\prime} 36.20^{\prime \prime} \mathrm{S}, 109^{\circ} 10^{\prime} 51.08^{\prime \prime} \mathrm{E}\right)$, Station II $\left(07^{\circ} 20^{\prime} 10.91^{\prime \prime} \mathrm{S}, 109^{\circ} 11^{\prime} 00.05^{\prime \prime} \mathrm{E}\right)$, Station III $\left(07^{\circ} 21^{\prime} 51.07^{\prime \prime} \mathrm{S}, 109^{\circ} 10^{\prime} 44.69^{\prime \prime} \mathrm{E}\right)$, Station IV

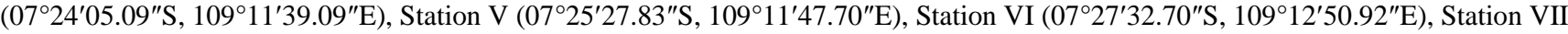
$\left(07^{\circ} 28^{\prime} 47.22^{\prime \prime} \mathrm{S}, 109^{\circ} 13^{\prime} 00.84^{\prime \prime} \mathrm{E}\right)$, and Station VIII $\left(07^{\circ} 29^{\prime} 45.79^{\prime \prime} \mathrm{S}, 109^{\circ} 13^{\prime} 02.58^{\prime \prime} \mathrm{E}\right)$. 
Table 1. Environmental conditions along the Logawa River, Banyumas District, Indonesia

\begin{tabular}{|c|c|c|c|c|c|c|c|c|}
\hline Characteristics & Station I & Station II & Station III & Station IV & Station V & Station VI & Station VII & Station VIII \\
\hline Coordinate & $\begin{array}{l}7^{\circ} 19^{\prime} 36.20^{\prime \prime} \mathrm{S} \\
109^{\circ} 10^{\prime} 51.08^{\prime \prime} \mathrm{E}\end{array}$ & $\begin{array}{l}7^{\circ} 20^{\prime} 10.91^{\prime \prime} \mathrm{S} \\
109^{\circ} 11^{\prime} 00.05^{\prime \prime} \mathrm{E}\end{array}$ & $\begin{array}{l}7^{\circ} 21 ' 51.07^{\prime \prime} \mathrm{S} \\
109^{\circ} 10^{\prime} 44.69^{\prime \prime} \mathrm{E}\end{array}$ & $\begin{array}{l}7^{\circ} 24^{\prime} 05.09^{\prime \prime} \mathrm{S} \\
109^{\circ} 11^{\prime} 39.09 \text { ” E }\end{array}$ & $\begin{array}{l}7^{\circ} 25 ’ 27.83 ” \mathrm{~S} \\
109^{\circ} 11^{\prime} 47.70^{\prime \prime} \mathrm{E}\end{array}$ & $\begin{array}{l}7^{\circ} 27^{\prime} 32.70^{\prime \prime} \mathrm{S} \\
109^{\circ} 12^{\prime} 50.92^{\prime \prime} \mathrm{E}\end{array}$ & $\begin{array}{l}7^{\circ} 28^{\prime} 28.47^{\prime \prime} \mathrm{S} \\
109^{\circ} 13^{\prime} 00.84^{\prime \prime} \mathrm{E}\end{array}$ & $\begin{array}{l}7^{\circ} 29^{\prime} 45.79^{\prime \prime} \mathrm{S} \\
109^{\circ} 13^{\prime} 02.58^{\prime \prime} \mathrm{E}\end{array}$ \\
\hline Altitude & $622 \mathrm{~m}$ asl. & $486 \mathrm{~m}$ asl. & $289 \mathrm{~m}$ asl. & $115 \mathrm{~m}$ asl. & $69 \mathrm{~m}$ asl. & $43 \mathrm{~m}$ asl. & $32 \mathrm{~m}$ asl. & $31 \mathrm{~m}$ asl. \\
\hline Riverside & $\begin{array}{l}\text { - Forest } \\
\text { - Garden (agricultural } \\
\text { areas) }\end{array}$ & $\begin{array}{l}\text { - Garden } \\
\text { - Settlement (municipal } \\
\text { areas) }\end{array}$ & $\begin{array}{l}\text { - Rained rice field } \\
\text { - Settlement }\end{array}$ & $\begin{array}{l}\text { - Rained rice field } \\
\text { - Settlement }\end{array}$ & $\begin{array}{l}\text { - Irrigated rice field } \\
\text { - Settlement }\end{array}$ & $\begin{array}{l}\text { - Irrigated rice } \\
\text { field } \\
\text { - Settlement }\end{array}$ & $\begin{array}{l}\text { - Irrigated rice field } \\
\text { - Garden } \\
\text { - Settlement }\end{array}$ & $\begin{array}{l}\text { - Moor } \\
\text { - Garden }\end{array}$ \\
\hline Substrate types & $\begin{array}{l}\text { - Bedrock }(40 \%) \\
\text { - Boulder }(35 \%) \\
\text { - Cobble }(15 \%) \\
\text { - Gravel }(10 \%)\end{array}$ & $\begin{array}{l}\text { - Boulder }(50 \%) \\
\text { - Cobble }(30 \%) \\
\text { - Gravel }(20 \%)\end{array}$ & $\begin{array}{l}\text { - Boulder }(40 \%) \\
\text { - Cobble }(30 \%) \\
\text { - Gravel }(15 \%) \\
\text { - Sand }(15 \%)\end{array}$ & $\begin{array}{l}\text { - Boulder }(25 \%) \\
\text { - Cobble }(25 \%) \\
\text { - Gravel }(25 \%) \\
\text { - Sand }(15 \%) \\
\text { - Silt }(10 \%)\end{array}$ & $\begin{array}{l}\text { - Boulder }(10 \%) \\
\text { - Cobble }(25 \%) \\
\text { - Gravel }(35 \%) \\
\text { - Sand }(20 \%) \\
\text { - Silt }(10 \%)\end{array}$ & $\begin{array}{l}\text { - Cobble }(20 \%) \\
\text { - Gravel }(40 \%) \\
\text { - Sand }(30 \%) \\
\text { - Silt }(10 \%)\end{array}$ & $\begin{array}{l}\text { - Cobble }(5 \%) \\
\text { - Gravel }(40 \%) \\
\text { - Sand }(45 \%) \\
\text { - Silt }(10 \%)\end{array}$ & $\begin{array}{l}\text { - Cobble }(10 \%) \\
\text { - Gravel }(40 \%) \\
\text { - Sand }(30 \%) \\
\text { - Silt }(20 \%)\end{array}$ \\
\hline $\begin{array}{l}\text { Human } \\
\text { activities }\end{array}$ & $\begin{array}{l}\text { - Garden fertilization } \\
\text { - Fishing }\end{array}$ & $\begin{array}{l}\text { - Garden fertilization } \\
\text { - Fishing }\end{array}$ & $\begin{array}{l}\text { - Stone excavation } \\
\text { - Sand excavation } \\
\text { - Fishing }\end{array}$ & $\begin{array}{l}\text { - Stone excavation } \\
\text { - Sand excavation } \\
\text { - Fishing }\end{array}$ & Fishing & Fishing & $\begin{array}{l}\text { - Stone excavation } \\
\text { - Sand excavation } \\
\text { - Fishing }\end{array}$ & $\begin{array}{l}\text { - Stone excavation } \\
\text { - Sand excavation } \\
\text { - Fishing }\end{array}$ \\
\hline Width & $12.0 \pm 1.22 \mathrm{~m}$ & $10.8 \pm 1.10 \mathrm{~m}$ & $15.3 \pm 2.22 \mathrm{~m}$ & $23.8 \pm 0.84 \mathrm{~m}$ & $17.2 \pm 1.30 \mathrm{~m}$ & $23.4 \pm 1.14 \mathrm{~m}$ & $25.8 \pm 0.84 \mathrm{~m}$ & $80.8 \pm 0.45 \mathrm{~m}$ \\
\hline Depth & $0.3 \pm 0.06 \mathrm{~m}$ & $0.3 \pm 0.04 \mathrm{~m}$ & $0.2 \pm 0.06 \mathrm{~m}$ & $0.1 \pm 0.02 \mathrm{~m}$ & $0.2 \pm 0.05 \mathrm{~m}$ & $0.2 \pm 0.05 \mathrm{~m}$ & $0.6 \pm 0.04 \mathrm{~m}$ & $3.2 \pm 0.16 \mathrm{~m}$ \\
\hline $\begin{array}{l}\text { Location } \\
\text { Village } \\
\text { Sub-district }\end{array}$ & $\begin{array}{l}\text { Baseh } \\
\text { Kedungbanteng }\end{array}$ & $\begin{array}{l}\text { Baseh } \\
\text { Kedungbanteng }\end{array}$ & $\begin{array}{l}\text { Sunyalangu } \\
\text { Karanglewas }\end{array}$ & $\begin{array}{l}\text { Jipang } \\
\text { Karanglewas }\end{array}$ & $\begin{array}{l}\text { Karanglewas Kidul } \\
\text { Karanglewas }\end{array}$ & $\begin{array}{l}\text { Sidaboa } \\
\text { Patikraja }\end{array}$ & $\begin{array}{l}\text { Kedungrandu } \\
\text { Patikraja }\end{array}$ & $\begin{array}{l}\text { Notog } \\
\text { Patikraja }\end{array}$ \\
\hline
\end{tabular}


Crustacean and water quality samplıng was carried out from upstream to downstream in longitudinal order. Crustacean sampling was carried out at eight stations (Figure 1). Crustacean samples were collected using a Surber net and water samples were collected using a water sampler with three replicates collected by switching location at each station at 20-minute intervals. In total, 120 samples were collected ( 8 stations $\times 3$ plots $\times 5$ replicates).

In the field, crustacean specimens were washed using clean running water, soaked immediately in plastic bags containing aqua dest, and then placed in plastic bags containing 96\% alcohol solution for preservation. Bags were labeled with the location of the sampling station. In the laboratory, crustacean specimens were placed in specimen bottles containing 96\% alcohol solution for preservation. These bottles were again labeled with the location of the sampling station.

For water quality samples, jerry cans were cleaned and filled with water in the field. These were labeled with the location of the sampling station. Samples were put inside a cool box at $4{ }^{\circ} \mathrm{C}$ and transported to the laboratory within 8 hours.

\section{Crustacean identification}

Observations of shrimp and crab samples included the rostrum, post antennular shape, teeth on the anterolateral edge, spines and setae on the first pereiopod, number of pereiopods, carpus size, merus size, chela size, location of pubescence on the second pereiopods, chela gap in the second pereiopods, tubercles in the chela, preanal carina, abdomen, uropod, and telson. Measurements made of shrimp and crab samples included the rostrum, length, peduncle antennular length, carapace thickness and width, first and second pereiopods (length of the carpus, merus, and chela). These data were needed for the crustacean identification process. Shrimp and crab samples were identified based on Chia and Ng (2006), Devi and Joseph (2017), Ng (2004), Yule and Sen (2004).

\section{Water quality analysis}

Thirteen physical and chemical water quality parameters were tested. Physical variables included transparency, current velocity, flow velocity, temperature, and total suspended solids (TSS), and chemical parameters were $\mathrm{pH}$, dissolved oxygen (DO), biochemical oxygen demand (BOD), chemical oxygen demand (COD), sulfide $\left(\mathrm{H}_{2} \mathrm{~S}\right)$, nitrate $\left(\mathrm{NO}_{3}\right)$, phosphate $\left(\mathrm{PO}_{4}\right)$, and ammonia $\left(\mathrm{NH}_{3}\right)$. These were analyzed using the Winkler and spectrophotometric methods based on APHA, AWWA, and WEF (2012).

\section{Data analysis}

Species richness was evaluated by Paleontological Statistics ver. 4.01, 1999-2020, for observed and estimated species, including Chao 1, Chao 2, Jackknife 1, Jackknife 2, and Bootstrap analyses (Hammer 2020). Environmental conditıon data by species were analyzed by Spearman rank correlation using IBM SPSS Statistics ver. 25, 2017 (IBM Corp., Armonk, NY, USA), for relationships between physical, chemical, and biological parameters. Dendrograms were obtained based on the similarity (\%) matrix among the species assemblage from each sampling site and species distribution along the longitudinal gradient (IBM 2017). Longitudinal distribution was also analyzed descriptively and presented in the form of distribution patterns (Iglikowska and Namiotko 2012; Suryaningsih et al. 2018).

\section{RESULTS AND DISCUSSION}

\section{Species richness}

This research A total of six species of Decapoda were identified in this study (Table 2). The decapods were in three families: the Palaemonidae (Macrobrachium cowlesi, M. idae, and M. oenone), Gecarcinidae (Parathelphusa bogoriensis and $P$. convexa), and Varunidae (Varuna litterata) (Table 3). The observed species richness was an overestimate compared to the high means and standard deviations of the Chao 2 and Bootstrap analyses. Cumberlidge et al. (2014) noted that the use of the latest version of the software has corrected the previous former version. Jackknife 1 and 2 estimates were more reliable for correcting the bias of these decapods in Logawa River (the mean and standard deviation values of observed species richness were close to the estimates of 6; Table 2). By station, Chao 1 fit Station VII (lower and upper values were detected at 3; Table 2) better than other stations, especially Station IV (lower and upper values were detected at 2 and 10, respectively).

The number of individuals of $M$. idae was the highest, followed by $M$. cowlesi, $M$. oenone, $P$. convexa, $P$. bogoriensis, and V. litterata. M. idae was a cosmopolitan species that inhabited all stations (Table 3).

All water quality parameters fluctuated, except temperature, $\mathrm{NH}_{3}, \mathrm{COD}$, and $\mathrm{pH}$. The temperature, $\mathrm{NH}_{3}$, and COD tended to increase, whereas the $\mathrm{pH}$ tended to decrease from Station I to Station VIII (Table 4).

Among the world's lobsters, freshwater crabs, freshwater crayfish, and freshwater shrimp, 2,878 species were assessed in the International Union for Conservation of Nature's (IUCN) Red List of Threatened Species Version 2019-2. Those species assessed included $M$. cowlesi, M. idae, M. oenone, $P$. bogoriensis, and $P$. convexa.

Macrobrachium cowlesi was not present at Station I. The dominant substrate type at Station I was bedrock (40\%; Table 1) which was not a preferred habitat for this species. Therefore, bedrock was evaluated as a threat to this species. Starting from Station II, boulders began to dominate the substrate $(50 \%)$ and $M$. cowlesi began to appear. 
Table 2. Observed and estimated species richness along the Logawa River, Banyumas, Indonesia

\begin{tabular}{|c|c|c|c|c|c|c|c|c|c|c|}
\hline Species richness & & Total & $\mathbf{I}$ & II & III & IV & V & VI & VII & VIII \\
\hline Observed species richness & & 6 & $2(1-2)$ & $5(2-3)$ & $5(1-5)$ & $5(2-5)$ & $4(3-4)$ & $5(4-5)$ & $3(3-3)$ & $4(3-4)$ \\
\hline Estimated species richness & Chao 1 & & $2(1-3)$ & $5(2-6)$ & $5(1-5)$ & $5(2-10)$ & $4(3-5)$ & $5(4-8)$ & $3(3-3)$ & $4(3-7)$ \\
\hline \multirow{4}{*}{ Estimated total species richness } & Chao 2 & $5.65 \pm 0.54$ & & & & & & & & \\
\hline & Jackknife 1 & $6.04 \pm 0.86$ & & & & & & & & \\
\hline & Jackknife 2 & $6.11 \pm 1.32$ & & & & & & & & \\
\hline & Bootstrap & $5.34 \pm 0.63$ & & & & & & & & \\
\hline
\end{tabular}

Table 3. Crustacean along the Logawa River, Banyumas, Indonesia

\begin{tabular}{|c|c|c|c|c|c|c|c|c|c|}
\hline Species & Unit & I & II & III & IV & $\mathbf{V}$ & VI & VII & VIII \\
\hline M. cowlesi & individual & & $0.2 \pm 0.45$ & $0.4 \pm 0.89$ & $0.8 \pm 1.30$ & $2.8 \pm 2.59$ & $4.6 \pm 5.55$ & $2.6 \pm 4.34$ & $0.8 \pm 1.79$ \\
\hline M. idae & individual & $1.2 \pm 2.68$ & $1.8 \pm 2.49$ & $0.4 \pm 0.89$ & $0.8 \pm 1.71$ & $2.8 \pm 2.05$ & $4.6 \pm 3.03$ & $2.6 \pm 3.60$ & $1.0 \pm 1.46$ \\
\hline M. oenone & individual & $1.0 \pm 1.22$ & $2.8 \pm 3.83$ & $1.0 \pm 1.00$ & $0.2 \pm 0.45$ & $1.0 \pm 1.22$ & $9.0 \pm 3.94$ & & $1.0 \pm 0.55$ \\
\hline P. bogoriensis & individual & & $0.2 \pm 0.45$ & $0.2 \pm 0.45$ & $0.2 \pm 0.45$ & & & & \\
\hline P. convexa & individual & & $0.8 \pm 1.79$ & $0.6 \pm 0.89$ & $2.6 \pm 3.21$ & $4.0 \pm 3.67$ & $5.2 \pm 1.64$ & $3.8 \pm 1.48$ & $3.6 \pm 1.82$ \\
\hline$V$. litterata & individual & & & & & & $0.2 \pm 0.45$ & & \\
\hline
\end{tabular}

Table 4. Water quality along the Logawa River, Banyumas, Indonesia

\begin{tabular}{|c|c|c|c|c|c|c|c|c|c|c|}
\hline Parameter & Unit & I & II & III & IV & $\mathbf{V}$ & VI & VII & VIII & Std \\
\hline Transpare & $\mathrm{m}$ & \pm 0 & $3 \pm 0.04$ & $2 \pm 0$ & $1 \pm 0.02$ & $2 \pm 0.05$ & $2 \pm 0.05$ & $0.5 \pm 0.01$ & $0.5 \pm 0$ & \\
\hline Current velocity & 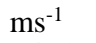 & $9 \pm 0.22$ & $0.9 \pm 0.12$ & $8 \pm 0.13$ & $0.6 \pm 0.08$ & $.8 \pm 0.15$ & $0.9 \pm 0.22$ & $0.1 \pm 0.03$ & $0.2 \pm 0$ & \\
\hline Flow velocity & $\mathrm{m}^{3} \mathrm{~s}^{-1}$ & $3.2 \pm 1.39$ & $2.4 \pm 0.88$ & $2.7 \pm 0.84$ & $1.9 \pm 0.40$ & $3.1 \pm 0.70$ & $4.8 \pm 1.44$ & $2.1 \pm 0.47$ & $51.7 \pm 2.76$ & \\
\hline Temperature & ${ }^{\circ} \mathrm{C}$ & $18.2 \pm 0.45$ & $18.5 \pm 0.87$ & $19.8 \pm 0.84$ & $22.8 \pm 1.79$ & $24.2 \pm 2.49$ & $25.8 \pm 0.45$ & $26.6 \pm 0.55$ & $26.8 \pm 0.84$ & \pm 3 \\
\hline TSS & $\mathrm{mgL}^{-1}$ & $1.6 \pm 0.49$ & $0.7 \pm 0.23$ & $14.0 \pm 6.92$ & $138.6 \pm 21$ & $19.1 \pm 3.94$ & $13.3 \pm 1.75$ & $17.2 \pm 5.67$ & $62.4 \pm 8.77$ & $<400$ \\
\hline $\mathrm{pH}$ & $\mathrm{mgL}^{-1}$ & $7.0 \pm 0$ & $7.0 \pm 0$ & $7.0 \pm 0$ & $6.8 \pm 0$ & $6.0 \pm 0$ & $6.0 \pm 0$ & $6.0 \pm 0$ & $6.0 \pm 0$ & $6-9$ \\
\hline DO & $\mathrm{gL}^{-1}$ & $8.6 \pm 0.92$ & $8.6 \pm 0.93$ & $8.9 \pm 0.77$ & $9.6 \pm 1.45$ & $9.4 \pm 0.93$ & $6.9 \pm 1.50$ & $7.5 \pm 2.61$ & $5.9 \pm 1.89$ & $>3$ \\
\hline BOD & $\mathrm{gL}^{-1}$ & $1.29 \pm 0.24$ & $2.02 \pm 0.52$ & $1.58 \pm 0.36$ & $1.43 \pm 0.39$ & $1.97 \pm 0.28$ & $1.96 \pm 0.16$ & $2.06 \pm 0.96$ & $2.82 \pm 1.64$ & $<6$ \\
\hline COD & $\mathrm{mgL}^{-1}$ & $34.8 \pm 2.28$ & $42.8 \pm 1.64$ & $31.8 \pm 7.64$ & $76.0 \pm 8.55$ & $54.2 \pm 9.85$ & $51.4 \pm 9.63$ & $76.6 \pm 6.35$ & $131.2 \pm 6.3$ & $<50$ \\
\hline $\mathrm{H}_{2} \mathrm{~S}$ & I -1 & nd & & nd & nd & & nd & nd & nd & $<0.002$ \\
\hline $\mathrm{NC}$ & $\mathrm{gL}^{-1}$ & $0.127 \pm 0.1$ & $0.086 \pm 0.1$ & $0.144 \pm 0.1$ & $0.272 \pm 0.1$ & $0.584 \pm 0.2$ & $0.869=$ & 0.81 & $0.845 \pm 0.2$ & $<20$ \\
\hline PO & -1 & $0.027 \pm 0.1$ & & $0.018 \pm 0.1$ & & & & & $0.030 \pm 0.1$ & $<1$ \\
\hline $\mathrm{NH}_{3}$ & $\mathrm{mgL}^{-1}$ & $1.103 \pm 0.1$ & $1.288 \pm 0.2$ & $1.404 \pm 0.2$ & $1.227 \pm 0.1$ & $1.179 \pm 0.2$ & $1.458 \pm 0.4$ & $1.524 \pm 0.6$ & $1.494 \pm 0.7$ & 0 \\
\hline
\end{tabular}

Note: nd: not detected, Std: standard

$\mathrm{NH}_{3}$ concentrations in the river were relatively high, exceeding the permissible surface water quality standard at all stations (Table 4). High concentrations of $\mathrm{NH}_{3}$ originate from agricultural, municipal, and industrial runoff discharged into rivers (Zheng et al. 2012; Warner et al. 2016; Nuruzzaman et al. 2017; Melki et al. 2018; Van Zelm 2020). Along the Logawa River, agricultural and municipal areas were dominant. Inorganic material entering the Logawa River came mainly from garden and rice field activities in agricultural areas, whereas organic material entering the Logawa River originated mainly from settlement activities in municipal areas. Both activities discharged waste into the river, leading to elevated $\mathrm{NH}_{3}$ concentrations (Figure 2). Garden fertilization activities such as nitrogen, phosphorus, and kalium fertilizers began from Station I. This resulted in an increase of $\mathrm{NH}_{3}$ with the increase of temperature ( $\mathrm{p}<0.05 ; \mathrm{r}=0.762)$ at Station VIII. $\mathrm{NH}_{3}$ increased with temperature (Table 4) from upstream $\left(18.2^{\circ} \mathrm{C}\right)$ to downstream $\left(26.8^{\circ} \mathrm{C}\right)$ following the topography from high altitude at Station I to low altitude at Station VIII, before decreasing when the river was wide and deep at Station VIII (Table 1). Increases were also found in $\mathrm{NO}_{3}$ and $\mathrm{PO}_{4}(\mathrm{p}<0.05 ; \mathrm{r}=0.719)$. The increase in $\mathrm{NO}_{3}$ resulted in a decrease in $\mathrm{pH}(\mathrm{p}<0.05 ; \mathrm{r}=-0.913)$ while the increase in $\mathrm{PO}_{4}$ resulted in a decrease in DO $(\mathrm{p}<$ $0.05 ; \mathrm{r}=-0.795$ ) because oxygen is needed in the nitrification process.

COD concentrations were relatively high, exceeding the permissible surface water quality standards between Stations IV and VIII, and tended to increase towards downstream areas (Table 4 and Figure 3). According to Iloms (2020), high concentrations of COD are sourced from waste oil that enters the river. Oil entering the waters of the Logawa River comes from areas near settlements starting from Station IV (Figure 1). Increased COD impacts water quality and adaptation strategies for macrobenthic 
organisms (Mahazar et al. 2013; Woke et al. 2014; Yusop et al. 2017). Similar to $\mathrm{NH}_{3}$, COD increased concurrently with temperature $(\mathrm{p}<0.01 ; \mathrm{r}=0.905)$. The increase in COD resulted in a decrease in $\mathrm{pH}(\mathrm{p}<0.05 ; \mathrm{r}=-0.782)$ between Stations IV and VIII as waters became acidic due to $\mathrm{NH}_{3}$ pollution (Table 4).

According to De Grave and Wowor (2013), M. cowlesi (Holthuis, 1950 in Animalia: Arthropoda: Malacostraca: Decapoda: Palaemonidae) is classified as Data Deficient (DD) for factors such as occurrence, ecological requirements, population size, population trends, and long- term threats to freshwater habitat, especially in rivers. The threats to this species are unknown.

Macrobrachium idae was present at all stations and tended to be able to live on the existing substrate (Table 1) and under the observed water quality conditions (Table 3 ). According to De Grave et al. (2013a), M. idae (Heller, 1862 in Animalia: Arthropoda: Malacostraca: Decapoda: Palaemonidae) is categorized as of Least Concern (LC), occupying stagnant freshwater and estuarine habitats, especially in lowland areas. The specific threats to this species are unidentified.
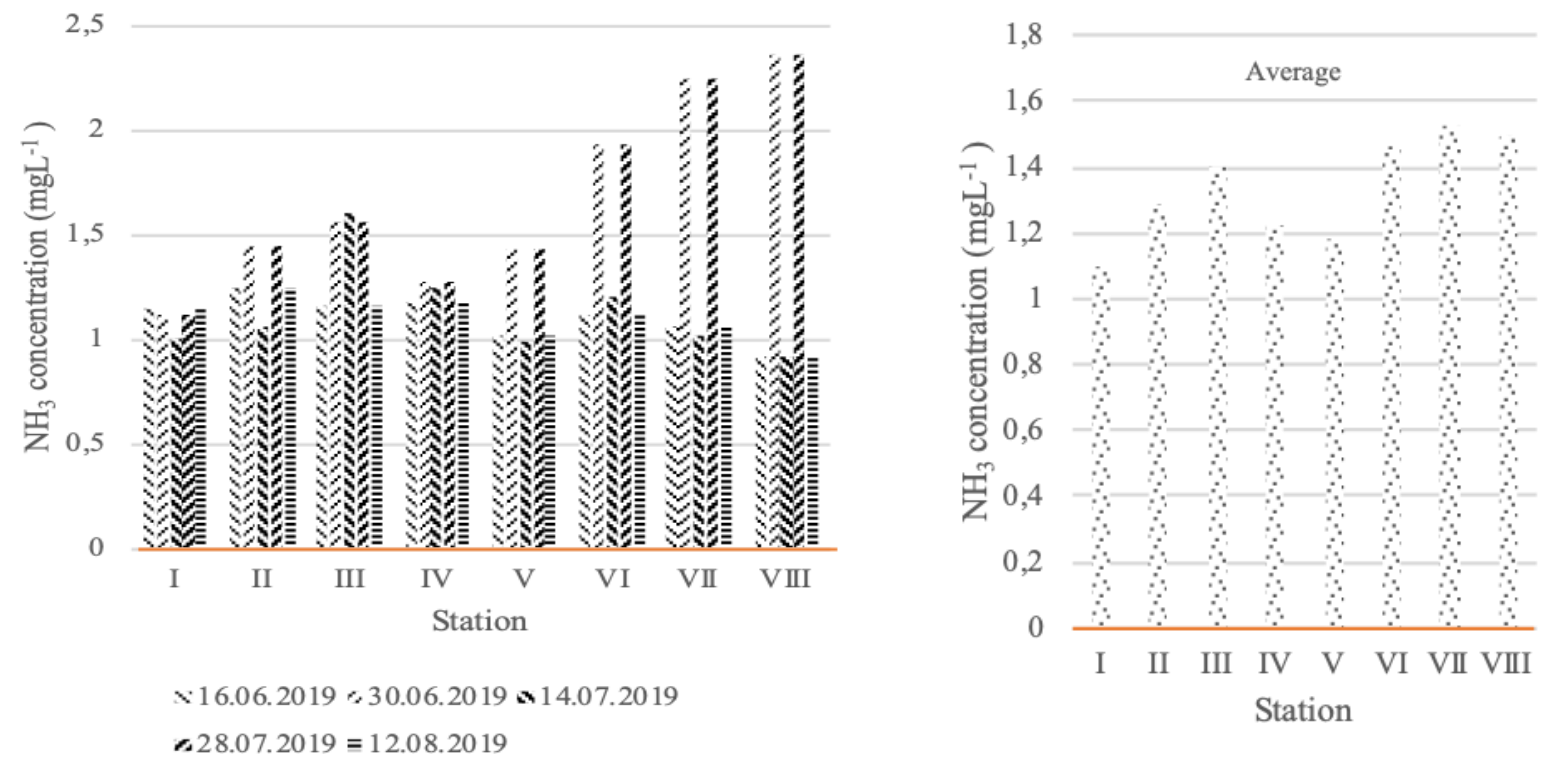

Figure 2. $\mathrm{NH}_{3}$ concentration along the Logawa River, Banyumas, Indonesia, where the red line indicates the water quality standard of 0 $\mathrm{mgL}^{-1}$ based on Government Regulation of the Republic of Indonesia Number 82 Year 2001
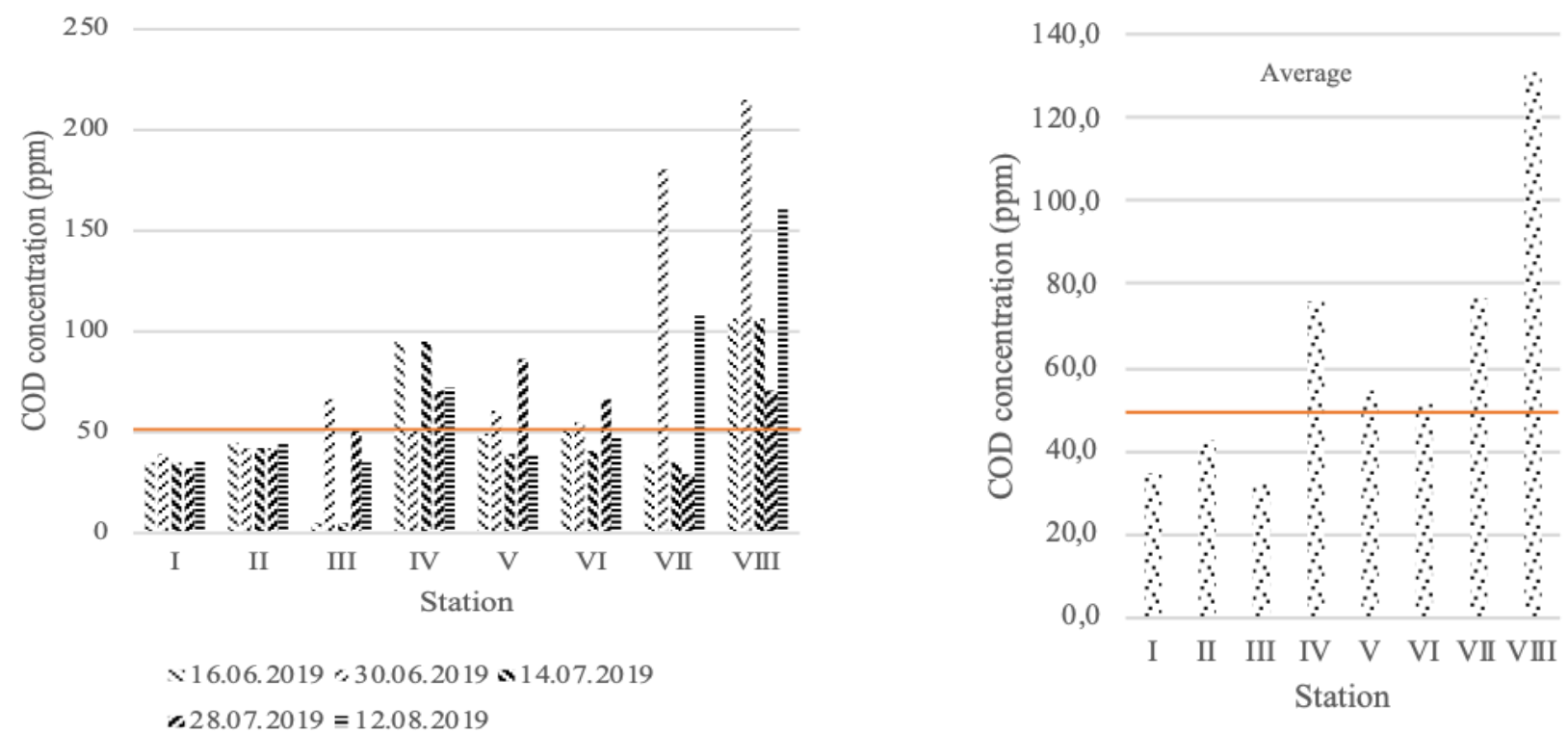

Figure 3. COD concentration along the Logawa River, Banyumas, Indonesia, where the red line indicates the water quality standard of $<50 \mathrm{mgL}^{-1}$ based on Government Regulation of the Republic of Indonesia Number 82 Year 2001 


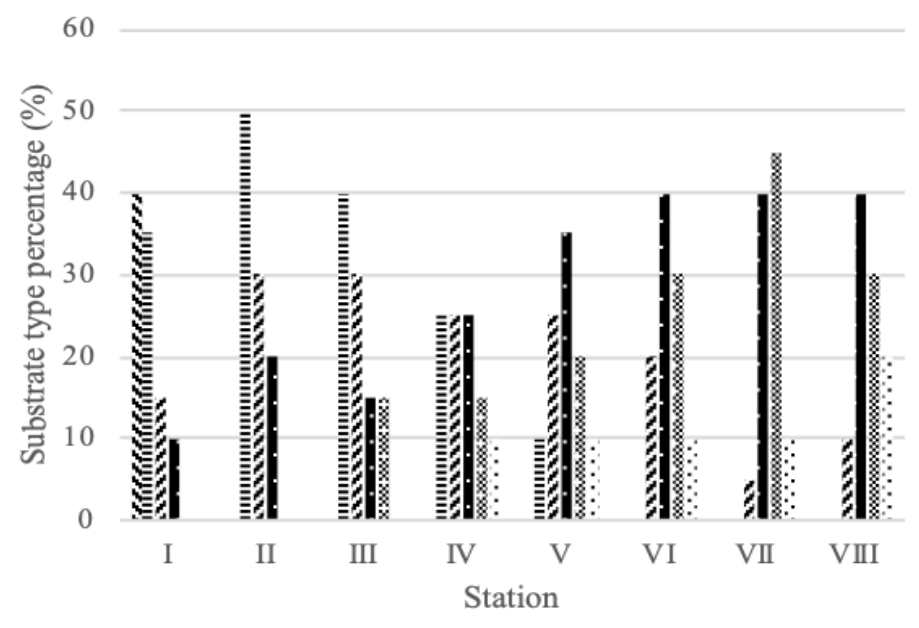

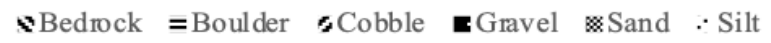

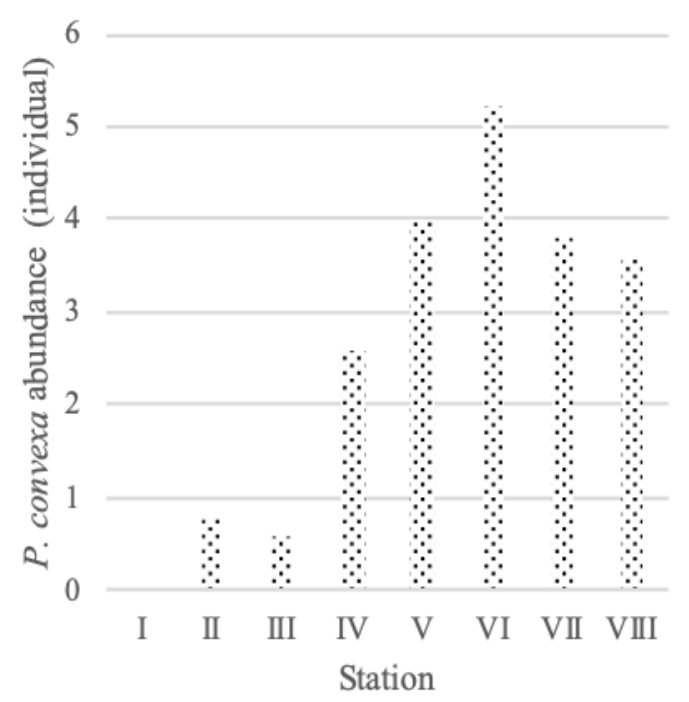

B

Figure 4. The percentage of substrate type (A) and the abundance of Parathelphusa convexa (B) along the Logawa River, Banyumas, Indonesia

As a cosmopolitan species, $M$. idae was able to use all stations as habitat. A specific threat was evaluated at Station III, which had the lowest abundance of individuals ( 0.4 individual) compared to the other stations, because locals had instigated activities such as stone and sand excavations, especially at Station III. These activities were also found at Stations IV, VIII, and VIII. This resulted in decreasing boulder dominance and increases in gravel ( $\mathrm{p}<$ $0.05 ; \mathrm{r}=-0.900)$, sand $(\mathrm{p}<0.01 ; \mathrm{r}=-0.919)$, and silt $(\mathrm{p}<$ $0.01 ; \mathrm{r}=-0.869)$ at Station VIII.

Macrobrachium oenone was present at all stations except Station VII. According to De Grave et al. (2013b), M. oenone (De Man, 1902 in Animalia: Arthropoda: Malacostraca: Decapoda: Palaemonidae) is categorized as DD for parameters such as occurrence, ecological requirements, population size, population trends, and longterm threats in freshwater habitat. The specific habitat requirements are unknown. The threats to the species are unknown. The absence of $M$. oenone was thought to be due to the increase of $\mathrm{NH}_{3}$ at Station VII. $\mathrm{NH}_{3}$ was predicted to be a threat to this species.

Parathelphusa bogoriensis was present only between Stations II and IV. According to Esser and Cumberlidge (2008a), P. bogoriensis (Bott, 1970 in Animalia: Arthropoda: Malacostraca: Decapoda: Gecarcinidae) is categorized as LC in freshwater habitats. The specific habitat requirements are unknown. The threats to the species are habitat loss and pollution.

The dominant substrate type of bedrock at Station I caused the absence of $P$. bogoriensis. The high COD concentrations that began at Station IV were tolerated by $P$. bogoriensis but the accumulated COD concentrations between Stations $\mathrm{V}$ and VIII caused the absence of $P$. bogoriensis. Therefore, bedrock and COD were predicted as threats to this species.

The presence of $P$. convexa followed the same pattern as that of $M$. cowlesi. According to Esser and Cumberlidge (2008b), P. convexa (De Man, 1879 in Animalia: Arthropoda: Malacostraca: Decapoda: Gecarcinidae) is categorized as DD due to the paucity of data from freshwater habitats. The threats to the species are habitat loss and pollution.

Based on our research data, the presence of boulders was a factor in the decrease of $P$. convexa at Station II ( $p<$ $0.05 ; \mathrm{r}=-0.778)$. However, the presence of gravel was connected to an increase of this species at Station VI ( $\mathrm{p}<$ $0.05 ; r=0.815)$. These findings are shown in Figure 4. Therefore, the availability of boulders and COD were predicted to be threats to this species, while gravel seemed to facilitate their presence.

Varuna litterata was found only at Station VI after the branching of the Banjaran Stream. According to $\mathrm{Ng}$ and Davie (2019), V. litterata (Fabricius, 1798 in Animalia: Arthropoda: Malacostraca: Decapoda: Varunidae) is not on the Red List for freshwater, brackish, or marine habitats.

\section{Longitudinal distribution}

Of the six species collected, $M$. idae could be categorized as a cosmopolitan species. Based on Külköylüoglu et al. (2016), cosmopolitan species tend to adapt to all elevations and altitudinal conditions. Conversely, $V$. litterata was a rare species along the Logawa River. V. litterata can live in freshwater, brackish, and marine ecosystems. In this river, there was decreasing species richness after Station IV due to COD pollution from the riverside and human activities in the habitat, and at Station I due to the bedrock substrate conditions. Conversely, there was increasing species richness in the middle of the stream along the longitudinal gradient (Figure 5). Hazeri et al. (2019) reported that crustacean species depend on the availability of habitat structure. In detail, Silva-Junior et al. (2017) reported that decapods were more abundant in leaf litter substrates than in sandy areas. In the Logawa River, leaf litter substrate was predicted to have originated from the tributary before Station II and the stream before Stations IV, V, and VI (Figure 1). 

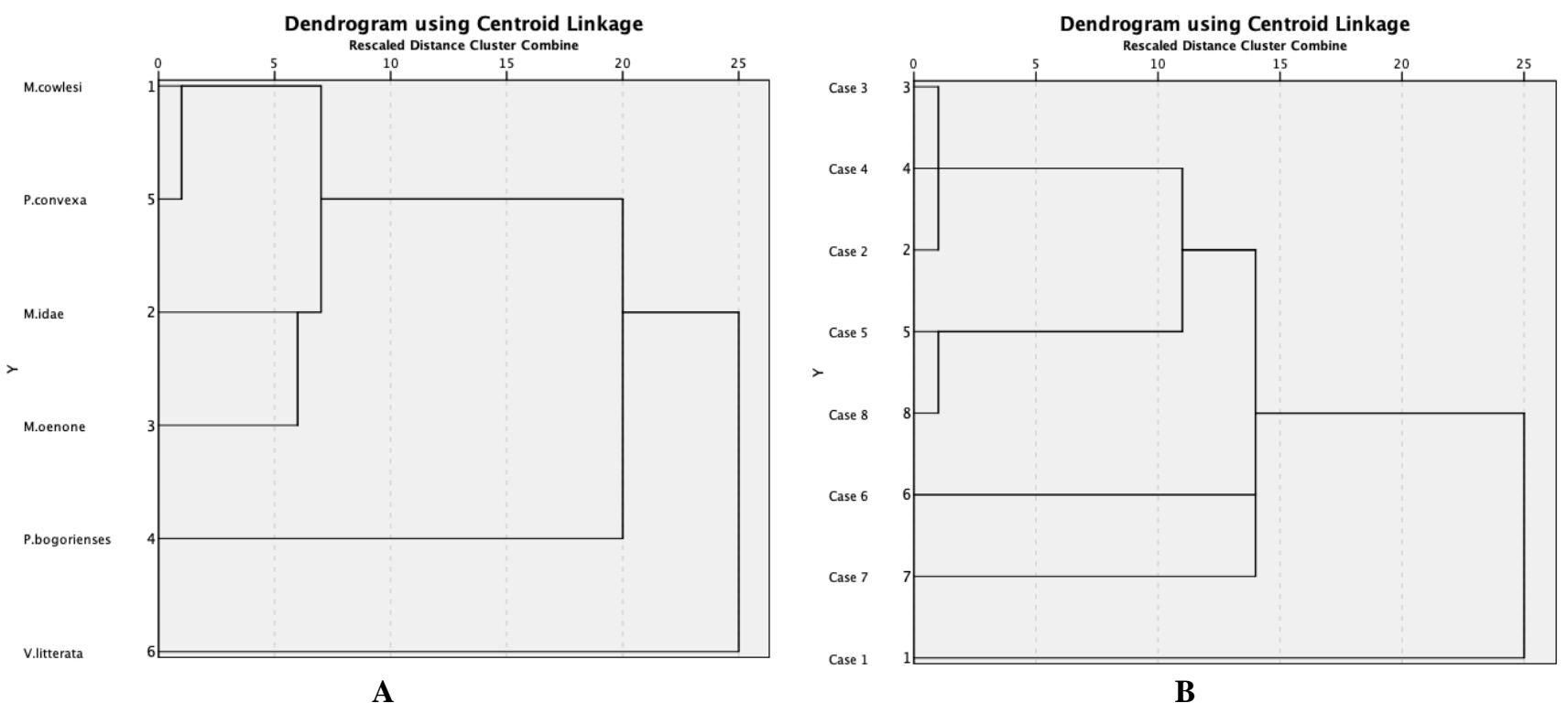

Figure 5. Crustacean species assemblage (A) and their distribution along the longitudinal gradient from Station I (Case 1) to Station VIII (Case 8) (B) along the Logawa River, Banyumas, Indonesia (IBM 2017)

In conclusion, the species richness of the six observed species fluctuated from upstream to downstream. In longitudinal distribution pattern, the cosmopolitan species M. idae lived at all stations, even in the presence of human disturbances such as water highly polluted by $\mathrm{NH}_{3}$ and COD, while the rare species $V$. litterata could not survive under these conditions. Unfortunately, stone and sand excavations and overfishing accelerated the process of crustacean habitat removal; naturally, crustaceans, except cosmopolitan species, do not prefer habitat with bedrock substrate.

\section{ACKNOWLEDGEMENTS}

The author would like to thank the Institute of Research and Community Service for providing opportunities to the Competency Improvement Research Program of Universitas Jenderal Soedirman in funding this research, number Kept.159/UN23/14/PN.01.00/2019. Thanks also goes to the Faculty of Biology at Universitas Jenderal Soedirman for giving access to the two laboratory facilities of the Aquatic Biology and Environmental Laboratory.

\section{REFERENCES}

Altermatt F, Alter R, Fišer C, Jokela J, Konec M, Küry D, Mächler E, Stucki P, Westram AM. 2014. Diversity and distribution of freshwater amphipod species in Switzerland (Crustacea: Amphipoda). PLoS ONE 9 (10): 1-12. e110328

APHA, AWWA, WEF. 2012. Standard methods. American Public Health Association, American Water Work Association, Water Environmental Federation, Washington.

Chia OKS, Ng PKL. 2006. The freshwater crabs of Sulawesi, with description of two new genera and four new species (Crustacea:
Decapoda: Brachyura: Parathelophusidae). Raffles Bull Zool 54 (2): 381-428.

Cumberlidge N, Alvarez F, Villalobos JL. 2014. Results of global conservation assessment of the freshwater crabs (Brachyura, Pseudothelphusidae and Trichodactylidae: The Neotropical region, with an update region, with an update on diversity. Zookeys 457: 133157

Deekae SN, Abowei JFN. 2010. Some age related attributes of Macrobrachium macrobrachion (Herklots, 1851) from Luubara Creek in Ogoni Land, Niger Delta, Nigeria. J Biol Sci 2 (5): 313-322.

Devi PL, Joseph A. 2017. On the record of herring bow crab Varuna litterata (Fabricus, 1798) from Cochin Backwaters, India. Indian J Geo Mar Sci 46 (5): 995-999

De Grave S, Wowor D. 2013. Macrobrachium cowlesi. The IUCN red list of threatened species 2013: e.T197828A2501767. www.iucnredlist.org

De Grave S, Wowor D, Ayhong S, Page T. 2013a. Macrobrachium idae. The IUCN red list of threatened species 2013: e.T198344A2521872. www.iucnredlist.org.

De Grave S, Cai Y, Wowor D. 2013b. Macrobrachium oenone. The IUCN red list of threatened species 2013: e.T197688A147786325. www.iucnredlist.org.

Duya N. 2008. Ichtiofauna perairan di Sungai Musi Kejalo Curup Bengkulu. Jurnal Gradien 4 (2): 394-396. [Indonesian]

Esser L, Cumberlidge N. 2008a. Parathelphusa bogoriensis. The IUCN red list of threatened species 2008: e.T134080A3891518. www.iucnredlist.org.

Esser L, Cumberlidge N. 2008b. Parathelphusa convexa. The IUCN red list of threatened species 2008: e.T134682A3997689. www.iucnredlist.org.

Hammer Ø. 2020. PAST: Paleontological Statistics Version 4.03. University of Oslo, Oslo.

Hazeri G, Rahayu DL, Subhan B, Sembiring A, Anggoro AW, Ghozali, Maduppa HH. 2019. Latitudinal species diversity and density of cryptic crustacean (Brachyura and Anomura) in micro-habitat Autonomous Reef Monitoring Structures across Kepulauan Seribu, Indonesia. Biodiversitas 20 (5): 1466-1474.

Howard JK, Klausmeyer KR, Fesenmeyer KA, Furnish J, Gardali T, Grantham T, Katz JVE, Kupverberg S, S, McIntyre P, Moyle PB, Ode PR, Peek R, Quiñones RM, Rehn AC, Santos N, Schoenig S, Serpa L, Shedd JD, Slusark J, Viers JH, Wright A, Morrison SA. 2015. Patterns of freshwater species richness, endemism, and vulnerability 
$\begin{array}{lllll}\text { in California PLoS ONE } 10 & \text { (7): e } 0130710\end{array}$ http://doi.org/10.1371/journal.pone.0130710

IBM 2017. IBM SPSS Statistics ver. 25.0. International Business Machines Corporation, New York.

Iglikowska A, Namiotko T. 2012. The impact of environmental factors on diversity of Ostracoda in freshwater habitats of subarctic and temperate Europe. Ann Zool Fenni 49: 193-218.

Iloms E, Ololade OO, Ogola HJO, Selvarajan R. 2020. Investigating industrial effluent impact on municipal wastewater treatment plant in Vaal, South Africa. Int J Environ Res Publ Health 17: 1096 www.mdpi.com/journal/ijerph.

Külköylüoglu O, Yavuzatmaca M, Sari N, Akdemir D, 2016. Elevational distribution and species diversity of freshwater Ostracoda (Crustacea) in Cankiri region (Turkey). J Freshw Ecol 32 (2): 219-230.

Lazo PX, Mosquera G, Mcdonnell J, Crespo P. 2019. The role of vegetation, soils, and precipitation on water storage and hydrological services in Andean Páramo catchments. J Hydrol 572: 805-819.

Mahazar A, Shuhaimi-Othman, Kutty AA. 2013. Benthic macroinvertebrate as biological indicator for water quality in Sungai Penchala. AIP Conference Proceedings 1571, 602 (2013). https://doi.org/10/1063/1.44858720.

Melki, Isnantyo A, Widada J, Murwantoko. 2018. The significance of water quality parameters on the diversity of ammonia-oxidizing bacteria in the water surface of Musi River, Indonesia. AACL Bioflux 11 (16): 1908-1918.

Ng PKL. 2004. Crustacea: Decapoda, Brachyura (Freshwater invertebrate of the Malaysian Region). Department of Biological Sciences, National University of Singapore, Singapore.

$\mathrm{Ng}$ PKL, Davie. 2019. WoRMS Brachyura: World list of marine Brachyura (version 2015-09-01). In: Roskov Y, Ower G, Orrell T, Nicolson D, Bailly N, Kirk PM, Bourgoin T, DeWalt RE, Decock W, Nieukerken E van, Zarucchi J, Penev L, (eds) Species 2000 \& IT IS Catalogue of Life, Annual checklist. www.cataloeoflife.org/annualchecklist $/ 2019$

Nuruzzaman M, Mamun AA, Salleh MNB. 2017. Determining ammonia nitrogen decay rate of Malaysian river water in a laboratory flume. Int
J Environ Sci Technol 15 (2): 1-10. https://doi.org/10.1007/s13762$107-1482-0$

Sastranegara MH, Pulungsari AE, Winarni ET, Kusbiyanto, Ramdani F, Andriyani L, Utari DN. 2020. Species richness and longitudinal distribution of Macrobenthos at River Pelus in Banyumas. Proceeding of The South-East Asian Conference on Biodiversity and Biotechnology. Purwokerto, 5-7 November 2018.

Silva-Junior EF, Silva-Araújo M, Moulton TP. 2017. Distribution and abundance of freshwater decapods in an Atlantic rainforest catchment with a dammed future. Braz J Biol 77 (4): 820-829.

Suryaningsih S, Sukmaningrum S, Simanjuntak, SB, Kusbiyanto. 2018. Diversity and longitudinal distribution of freshwater fish in Klawing River, Central java, Indonesia. Biodiversitas 19 (1): 85-92.

Van Zelm R, da Motta RDPS, Lam WY, Menkveld W, Broeder E. 2020. Life cycle assessment of side stream removal and recovery of nitrogen from wastewater treatment plants. J Ind Ecol 2020: 1-10. DOI: $10.1111 /$ jiec. 12993

Warner JX, Wei Z, Strow, LL, Dickerson RR, Nowak JB. 2016. The global tropospheric ammonia distribution as seen in the 13-year AIRS measurement record. Atmos Chem Phys 16: 5467-5479.

Wibowo DN, Setijanto, Santoso, S. 2017. Short communication: Benthic macroinvertebrate diversity as biomonitoring of organic pollution of river ecosystems in Central Java, Indonesia. Biodiversitas 18 (2): 671676.

Woke GN, Babatunde BB, Orie OC. 2014. Effects of abattoir wastes on benthic macroinvertebrates of the Elechi creek, Port Harcourt, Rivers State, Nigeria. Glob J Pure Appl Sci 20: 1-4.

Yule CM, Sen, YH. 2004. Freshwater Invertebrates of the Malaysian Region. Academy of Sciences Malaysia, Kualalumpur.

Yusop Z, Kadir AA, Noor ZZ. 2017. Benthic macroinvertebrate composition and water quality status in Sungai Johor, Johor, Malaysia. Chem Eng Trans 56: 187-192.

Zheng, JY, Yin SS, Kang DW, Che WW, Zhong LJ. 2012. Development and uncertainty analysis of a high-resolution $\mathrm{NH}_{3}$ emissions inventory and its implications with precipitation over the Pearl River Delta region, China. Atmos Chem Phys 12: 7041-7058. 